\title{
A Literature Review: Which Regulation is Feasible for Assessing User Satisfaction with Terminal Services?
}

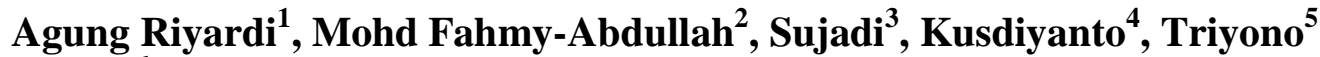 \\ ${ }^{I}$ Economics Department, Universitas Muhammadiyah Surakarta, Indonesia \\ ${ }^{2}$ Faculty of Technology Management and Business, Universiti Tun Hussein Onn, Parit Raja Batu Pahat, Johor \\ Darul Tak'zim, 86400, Malaysia \\ ${ }^{3}$ Management Department, Universitas Muhammadiyah Surakarta, Indonesia \\ ${ }^{4}$ Management Department, Universitas Muhammadiyah Surakarta, Indonesia \\ ${ }^{5}$ Economics Department, Universitas Muhammadiyah Surakarta, Indonesia \\ Agung.Riyardi@ums.ac.id
}

\begin{abstract}
Three different studies have discussed regulations of the assessment of user satisfaction levels with terminal services. Based on the assumption that the terminal attributes derived from regulations are accurate, this study aims to analyze the content of the regulations, compare them, and analyze terminal user satisfaction as assessed by previous studies. Content analysis of the literature is conducted. The results reveal that among the user satisfaction survey regulations from the Minister of Administrative and Bureaucratic Reform Regulations of 16/2014 and 25/2004 and the service standard regulations from the Minister of Transportation Regulation of 40/2015, the most feasible regulation for the assessment of user satisfaction is the Minister of Transportation Regulation of 40/2015. This regulation does not regulate satisfaction assessment but can be used as a basis for assessments of user satisfaction with terminal services. All of the stipulated service standards can be classified as accurate terminal service attributes. Therefore, improvements can be made by including a requirement for satisfaction assessments. Through the incorporation of the service quality concept, such improvement could establish this regulation as a basis for reputable studies of satisfaction assessments. Another result reveals that the literature on the assessment of terminal user satisfaction based on the Minister of Transportation Regulation of 40/2015 reports that users are satisfied with the terminal attributes of reliability, convenience, affordability and equity, but they are unsatisfied with the attributes of safety and security. Thus, terminals should implement maximal regulation of service standards. Assurance of terminal security could increase user satisfaction.
\end{abstract}

Keywords: Terminal; regulation; standards; attributes; satisfaction.

\section{Introduction}

The government and governmental agencies provide numerous services, and it is necessary to assess user satisfaction with these services. On the one hand, user satisfaction is a sensitive issue about the appropriate provision of services by the government that can be a constructive attribute for government continuity, while dissatisfaction can be a detrimental attribute. On the other hand, user satisfaction is also a basis for the improvement of government services because it provides information about which services are lacking. User satisfaction can be used as a tool for public satisfaction innovation. (Pramusinto, 2007).

The assessment of user satisfaction with government services is an interesting topic. Several studies have discussed user satisfaction in the realm of population administration, port infrastructure, land licensing, education, health, infrastructure and security. Liando (2012); Normajatun and Herman (2017); Rizq, Djamaludin, and Nurhadryani (2018); and Avianto (2018) examined service quality satisfaction for services of the User Administration and Civil Registration Office (Dinas Kependudukan dan Catatan Sipil). Yudiatmaja (2017) analyzed harbor users' dissatisfaction by evaluating the difference between expectations and 
perceptions. Hermawan, Budiman, and Hutagaol (2016) investigated the level of community satisfaction with the services of the National Land Agency (Badan Pertanahan Nasional= BPN). Santoso, Rosidah, and Prasetyo (2017) discussed user satisfaction with the features of libraries. Athiyah (2018) analyzed community satisfaction in relation to health centers (Pusat Kesehatan Masyarakat= Puskesmas). Auliya (2016) revealed customer satisfaction with the services of the Indonesian Electricity (Perusahaan Listrik Negara= PLN). Sumino and Sutrischastini (2017) discussed services of policy agencies. Meanwhile, Dirlanudin, Sjafari, Nafisah, Hakim, and Ade (2014) analyzed the level of user satisfaction with a variety of government agencies at the regency/city level.

User satisfaction with the services and facilities of bus terminals has also been a theme of various studies. Previous studies have investigated numerous attributes of studies of user satisfaction with bus terminals, including the types of terminals, the attributes of terminals, and the analytical tools in the research methodology (see Figure 1).

The type of bus terminal and user satisfaction have been discussed previously. Studies focused on large terminals have been carried out by Mokhlis (2007); Mulyanto (2007); Lushakuzi and Daudi (2014); Dana, Nane, Belete, Ergado, and Labiso (2016); Ishak and Madsah (2016); Ikhlaq, et al. (2017); and Angestiwi (2018). Furthermore, Lois, Monzón, and Hernández (2016); Abramović (2017); and Cheng, Cao, Huang, and Wang (2018) discussed integrated bus-train stations. These studies required accurate observations and a sufficient number of respondents as well as supporting data. Meanwhile, Handriyati, Sunaryo, and Helia (2015); Sukesi and Muliasari (2018); and Witjaksono, Suyatno, and Soeparno (2018) focused their studies on small terminals.

The research methods, particularly the analytical tools, are in important element in studies of user satisfaction with terminals. In studies focused on intervariable correlations, the required analytical tools are modeling, such as regressions and structural equation models (SEMs). Examples of such studies are those by Mokhlis (2007); Ishak and Madsah (2016); Cheng, Cao, Huang, and Wang (2018); and Yuan et al. (2019). In addition, studies that highlight the level of user satisfaction with terminals require other tools, including user satisfaction assessments, user satisfaction indexes, Cartesian diagrams and radar (spider) charts. Usually it is called Performance Analysis Methods. Mulyanto (2007); Lushakuzi and Daudi (2014); Sedayu (2014); Handriyati, Sunaryo, and Helia (2015); Olivková (2015); Dana, Nane, Belete, Ergado, and Labiso (2016); Abramović (2017); Ikhlaq, et al. (2017); Sukesi and Muliasari (2018); Angestiwi (2018); and Witjaksono, Suyatno, and Soeparno (2018), are among the researchers who have used such tools. De Oña \& de Oña (2014) elaborate all of analyses tools and conclude that analysis tools using indicates a public transport satisfaction survey approach evolution. 


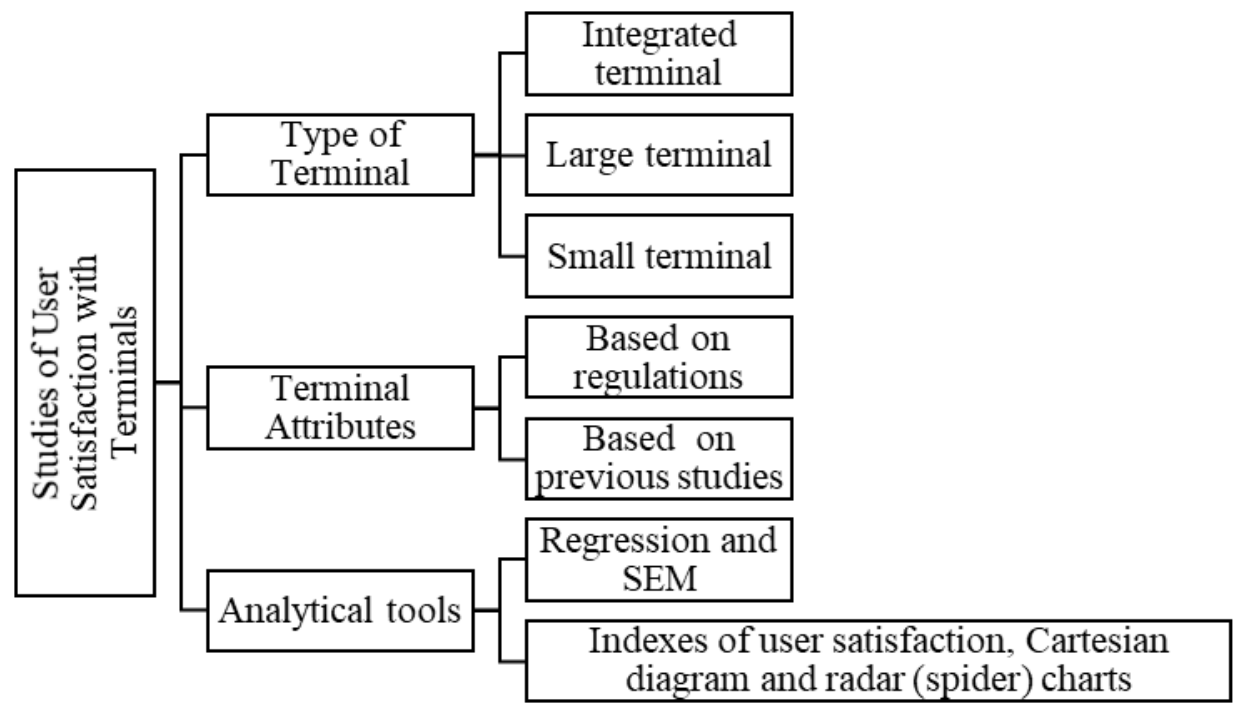

Figure 1. Details of studies of user satisfaction with bus terminals

Specific attributes have also been examined thoroughly. Several interesting discussions have focused on the selection of accurate attributes. Several studies, such as those of Mulyanto (2007), Gromure (2007), Angestiwi (2018), and Sukesi and Muliasari (2018), have examined attributes based on regulations. Meanwhile, other studies, such those of Handriyati, Sunaryo, and Helia (2015); Witjaksono, Suyatno, and Soeparno (2018); and Cheng, Cao, Huang and Wang (2018), have derived attributes from previous studies based on a service quality framework.

The present study reviews the research investigating the attributes of bus terminals based on existing regulations. This investigation is interesting since previous studies have used different regulations as the basis for determining certain attributes of terminal services. Moreover, based on our understanding, there has been no discussion of these conflicting regulations.

Government regulations guide the assessment of user satisfaction with services provided by the government to ensure that the government serves the user. In addition, such regulations avoid ineffective measurement of user satisfaction. Moreover, such regulations standardize the attributes of governmental users. Thus, attributes established in regulations are accurate attributes.

Two regulations have recently been issued regarding the assessment of user satisfaction with government services. The first is the Minister of Administrative and Bureaucratic Reform Regulation of $16 / 2014$ on the Guidelines for the Administration of the User Satisfaction Index on User Service Implementation. The second is the Minister of Transportation Regulation of 40/2015 on the Service Standards for Land Transport Terminals. In addition, a less recent regulation was the Minister of Administrative and Bureaucratic Reform Regulation of 25/2004 on the General Guidelines for the Preparation of the User Satisfaction Index of Service Units in Government Agencies. Therefore, there are three ministerial regulations that can be used to evaluate user satisfaction. Their existence raises questions about the content of each ministerial regulation in relation to the assessment 
of user satisfaction with government services, the differences between these regulations, and their implementation in the assessment of user satisfaction.

The present study is aimed at reviewing previous studies that have discussed the variety of regulations to assess the level of user satisfaction with bus terminal services. The study includes three objectives: to analyze the content of each regulation, compare the regulations, and analyze their implementation in assessments of user satisfaction. The fulfillment of the objectives will address the posed research questions.

Our findings show that the Minister of Transportation Regulation of 40/2015 is the best regulation. Through its regulation of terminal service standards, it provides terminal service attributes. It is not the most recent regulation, but it offers appropriate and complete attributes for studies of user satisfaction with terminal services. In addition, this regulation has been implemented in all terminals. Terminal users perceive the attributes of safety, security, reliability, convenience, affordability and equity.

The importance of the present study lies in its determination of the Minister of Transportation Regulation of 40/2015 as the most effective regulation. The study suggests that this regulation is the most appropriate for terminal user assessment studies. The six service standards provided by the regulation can be used as service attributes to examine. Relatedly, these service standards can be used to develop suggestions. Future research should use the regulation standards to formulate service quality attributes before assessing terminal user satisfaction. Furthermore, the study emphasizes the importance of user satisfaction assessments. Terminal users do not feel very satisfied with the provided services, which indicates the importance of terminal standardization and security.

This paper is structured in four sections. Section 2 details the literature content analysis method. Three steps are detailed. The steps are literatures content description, comparison and analysis. Section 3 discusses the result about the best regulation to assess user satisfaction with terminal services. Finally, section 4 concludes that aims of the research are reached and suggests future researches to consider the service standard regulation before assess the user satisfaction with terminal services.

\section{Research Method}

In this study, we conducted a literature content analysis. We compared several studies that address user satisfaction with terminals based on the prevailing regulations. The comparisons were focused on their literature review, method and results sections. We conducted the analysis in three stages. First, we reviewed their literature reviews and methods to understand the content of each regulation. Second, we compared the literature reviews and methods content to choose the best regulation. Third, we analyzed the results and discussion content to investigate the implementation of the best regulations to assess user satisfaction.

The description of the literature review and methods sections to understand the content of each regulation was performed in several stages. After three studies were selected, each regulation that was discussed was summarized, including the title and number of chapters and articles. Finally, the content of each regulation was detailed. If the literature review and method sections did not provide clear and sufficient information, we referred to the regulation itself. The comparison of the literature review and method sections to choose the best regulation was performed in two steps. After comparing the sections, we chose the best regulation based on three criteria: regulation issue date, accuracy and completeness. 
Based on the assumption that the studied terminals were implementing the selected best regulation, a comparison of the results and discussion sections to examine the implementation of this regulation to assess user satisfaction was performed in three steps. First, we reviewed the findings of the results and discussion sections of the literature on the selected best regulation. The findings concerned terminal service attributes and user satisfaction. Second, we compared these findings with those presented in the results and discussion sections of the literature focused on the other regulations. Third, we quantified the user satisfaction level for every terminal attribute. A score of 3 indicated "most satisfied", a score of 2 indicated "satisfied", and a score of 1 indicated "unsatisfied".

Three studies were selected to use their primary data. The first study was studied carried out by Mulyanto (2007) and analyzed the level of user satisfaction with Tirtonadi Terminal, Surakarta, Indonesia, based on the Minister of Administrative and Bureaucratic Reform Regulation of 25/2004. The second study was performed by Sukesi \& Muliasari (2018) that investigated user satisfaction with Larangan Terminal and Bunder Terminal based on the Minister of Administrative and Bureaucratic Reform Regulation of 16/2014. The third study was performed by Angestiwi (2018) on Leuwipanjang Terminal, Bandung, based on the Minister of Transportation Regulation of 40/2015.

Sukesi \& Yunus (2018) analysis does not used as a data. It is similar to Sukesi \& Muliasari (2018) in term of arguing the important of Minister of Administrative and Bureaucratic Reform Regulation of 16/2014. However, its object is intercity bus from Surabaya to Ponorogo, whilst our focus is terminal.

\section{Results and Discussion}

\subsection{Regulations of Terminal Services}

The existing literature has discussed three regulations that are generally used for the assessment of user satisfaction with terminals. Mulyanto (2007) focused on the first regulation, the Minister of Administrative and Bureaucratic Reform Regulation of 25/2004hereafter called the first regulation. The first regulation states that user satisfaction should be surveyed by government agencies. This regulation stipulates fourteen service attributes to measure user satisfaction. Sukesi \& Muliasari (2018) discussed the second regulation, the Minister of Administrative and Bureaucratic Reform Regulation of 16/2014-hereafter called the second regulation. The second regulation also states that user satisfaction must be carried out by government agencies. This regulation only stipulates nine attributes of user satisfaction. In addition, the regulation does not limit survey methods to quantitative methods. Angestiwi (2018) highlighted the third regulation, the Minister of Transportation Regulation of 40/2015-hereafter called the third regulation-that proposes six terminal service attributes. This regulation is accompanied by the Minister of User Work Regulation of 24/2008 about government building maintenance (Table 1).

However, this literature does not provide clear information about the service regulations. The studies' literature review sections only state the name of each regulation and that satisfaction surveys should be performed periodically, while their methods sections describe the service attributes mentioned by the regulations and methods used to quantify user satisfaction levels. Referring to the regulation themselves, the content of each regulation consists of the goal of the regulation, format of the regulation and attributes defined in the regulation. The goal of the first and second regulations is to stipulate the user satisfaction 
surveys and methods that should be conducted by governmental agencies yearly, while the goal of the third regulation is to establish service standards that should be provided by terminals to their users. The second regulation also notes that it replaces the first regulation. The first regulation has a numbered list format, while the second and third regulations have chapter and verse formats. The service attributes to be surveyed and the survey methods are described in the first and second regulations, while terminal service standards that can be derived as terminal attributes are described in the third regulation.

Table 1. Literature on regulations of user satisfaction surveys

\begin{tabular}{|c|c|c|c|}
\hline Paper & Mulyanto (2007) & $\begin{array}{l}\text { Sukesi and Muliasari } \\
(2018)\end{array}$ & Angestiwi (2018) \\
\hline $\begin{array}{l}\text { Section in the } \\
\text { Paper Describing } \\
\text { the Regulation }\end{array}$ & References & $\begin{array}{l}\text { Literature review and } \\
\text { methods }\end{array}$ & Methods \\
\hline $\begin{array}{l}\text { Name of the } \\
\text { Regulation }\end{array}$ & $\begin{array}{l}\text { Minister of } \\
\text { Administrative and } \\
\text { Bureaucratic } \\
\text { Reform Regulation } \\
\text { of } 25 / 2004\end{array}$ & $\begin{array}{l}\text { Minister of } \\
\text { Administrative and } \\
\text { Bureaucratic Reform } \\
\text { Regulation of } 16 / 2014\end{array}$ & $\begin{array}{l}\text { Minister of } \\
\text { Transportation } \\
\text { Regulation of } 40 / 2015\end{array}$ \\
\hline $\begin{array}{l}\text { Goal of the } \\
\text { Regulation }\end{array}$ & $\begin{array}{l}\text { To establish } \\
\text { guidelines for the } \\
\text { survey of user } \\
\text { satisfaction with } \\
\text { user services }\end{array}$ & $\begin{array}{l}\text { To establish } \\
\text { guidelines for the } \\
\text { survey of user } \\
\text { satisfaction with user } \\
\text { services }\end{array}$ & $\begin{array}{l}\text { To establish service } \\
\text { standards for land } \\
\text { transport terminals }\end{array}$ \\
\hline \multirow{3}{*}{ Content } & $\begin{array}{l}\text { User service units } \\
\text { must conduct } \\
\text { surveys of user } \\
\text { satisfaction based } \\
\text { on the index with } \\
\text { fourteen attributes. }\end{array}$ & $\begin{array}{l}\text { User service units } \\
\text { must conduct and } \\
\text { publish surveys of } \\
\text { user satisfaction based } \\
\text { on nine attributes. }\end{array}$ & $\begin{array}{l}\text { Terminals should } \\
\text { fulfill six attributes } \\
\text { and many sub- } \\
\text { attributes to serve } \\
\text { their users and should } \\
\text { consider the Minister } \\
\text { of Public Work } \\
\text { Regulation of } 24 / 2008 \\
\text { about government } \\
\text { building maintenance. }\end{array}$ \\
\hline & $\begin{array}{l}\text { The survey method } \\
\text { involves } \\
\text { interviewing } \\
\text { respondents with a } \\
\text { questionnaire } \\
\text { instrument. } \\
\text { Respondents are } \\
\text { obtained through } \\
\text { random sampling } \\
\text { techniques. }\end{array}$ & $\begin{array}{l}\text { The survey method } \\
\text { can be quantitative or } \\
\text { qualitative methods. } \\
\text { Respondents can be } \\
\text { obtained through } \\
\text { random sampling or } \\
\text { other techniques. }\end{array}$ & \\
\hline & Fourteen attributes: & Nine Attributes: & Six service attributes: \\
\hline
\end{tabular}




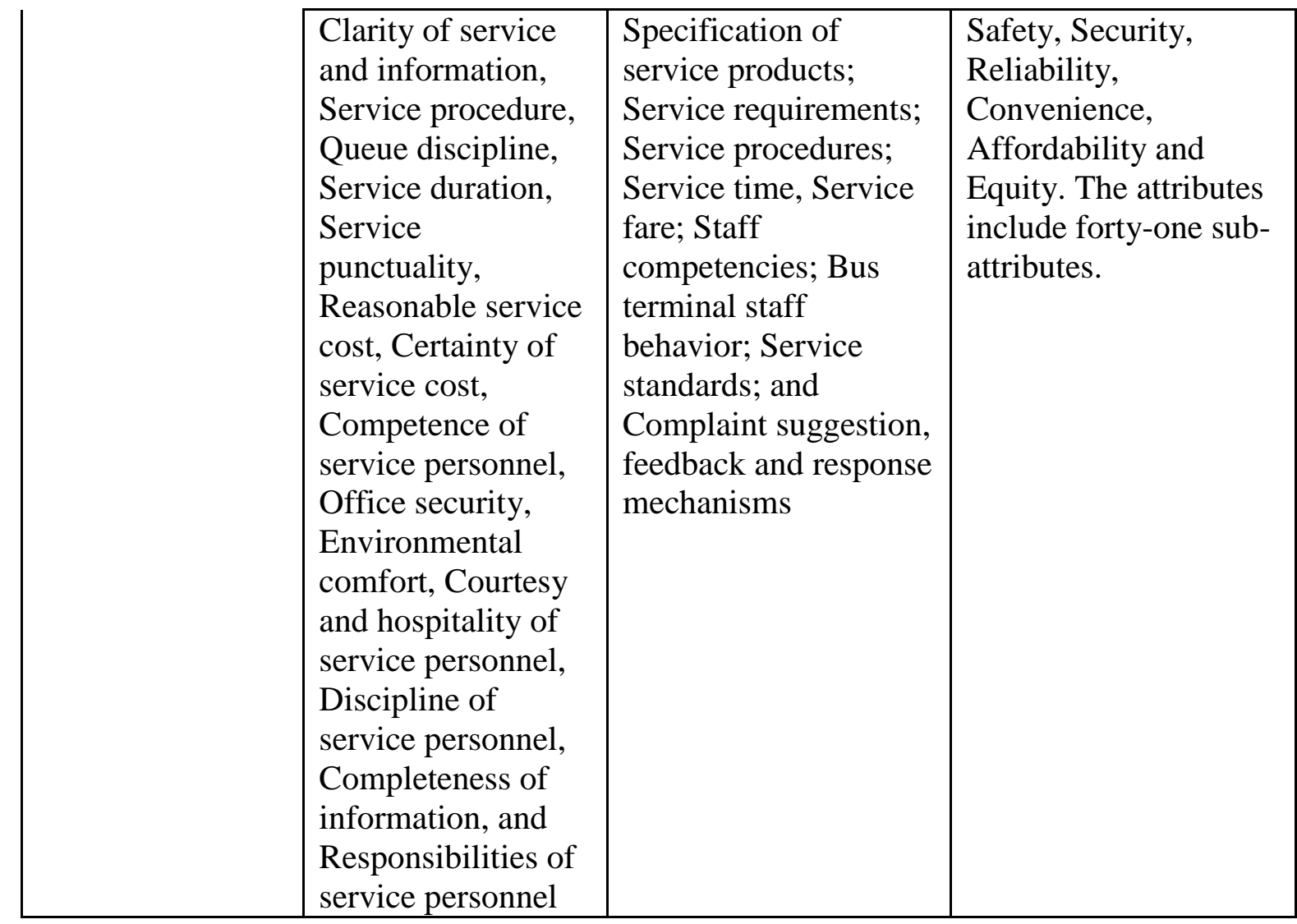

Source: Mulyanto (2007), Sukesi and Muliasari (2018) and Angestiwi (2018)

Regulations of terminal services can be used as a basis for the study of terminal bus user satisfaction. Two regulations focus on surveys to measure user satisfaction with governmental agency services, and one regulation focuses on terminal service standards. The regulations can be used by terminal user satisfaction studies because they provide accurate attributes of user satisfaction. Two of the regulations also provide a survey method. They can be used to establish regulation-based terminal service assessment studies.

Regulation-based terminal service assessment studies provide an alternative to terminal service terminal assessment studies that derive attributes from the service quality concept, such as those conducted by Handriyati, Sunaryo, and Helia (2015); Witjaksono, Suyatno, and Soeparno (2018); and Cheng, Cao, Huang, and Wang (2018). The main difference lies in the way the service attributes are derived. The former type of study derives attributes from regulations, while the latter type of study derives attributes from the service quality concept.

Terminal service attributes that are derived from regulations are accurate for at least three reasons. First, terminal regulations are important, as noted by Gromure (2007). Second, terminal regulations should be relevant to terminal stakeholders, such as central, provincial and regional governments; businesses; universities; and passengers. Third, regulations establish terminal general characteristics (Mulyanto, 2007).

\subsection{The Best Regulation}

Comparing the first and second regulations, we find both similarities and dissimilarities. One similarity is that the same ministry published regulations. Both the first 
and second regulations were issued by the Indonesian Ministry of Administrative and Bureaucratic Reform. Another similarity is that they regulate the survey of user satisfaction by government agencies. The dissimilarities concern the year the regulation was issued, the regulation format, the survey methods and the number of attributes to be surveyed. The second regulation was issued ten years after the first to improve the first regulation. The improvements are related to the format - from the use of single-level numbering to chapters and verses to describe the attributes, from the description of general to precise attributes and from the stipulation of only quantitative survey methods to both quantitative and qualitative survey methods.

Comparing the third regulation to the first and second regulations, we find several differences. The third regulation was not issued by the Indonesian Ministry of Administrative and Bureaucratic Reform but by the Indonesian Ministry of Transportation. In addition, it has been implemented in all terminals, while some government agencies have not implemented the first and second regulations (Lukito, 2016). Furthermore, the third regulation does not cover user satisfaction; rather, its purpose is to standardize terminal services. Moreover, it does not regulate terminal user satisfaction surveys. Instead, it regulates the terminal service standards that should be provided by terminal management. Another difference lies in the attributes of safety, security, reliability, convenience, affordability and equity. In the third regulation, these attributes are not sub-attributes of service requirements, as in the second regulation, but rather are the main attributes of terminal services.

From the comparisons, we find that the third regulation is the best regulation. It is the newest, most accurate and most complete regulation. Similar to the second regulation, it is more advanced than the first regulation, as can be seen in two aspects. First, the third regulation was published in 2015, while the first regulation was published in 2004, and the second regulation was published in 2014. Second, the studies on the second and third regulations were published in 2018, while the study on the first regulation was published in 2007. In addition, the third regulation is the most appropriate regulation to be used as a basis for studies of terminal user satisfaction because it was issued by the Ministry of Transportation, which has the competence to supervise terminals. Furthermore, the standards for terminal services stated in the regulation can be used to derive terminal attributes to facilitate the definition of accurate attributes in studies of terminal user satisfaction. The regulation also provides opportunities to expand the scope of such studies through the examination of the maintenance of the regulation in terminals. In contrast, the first and second regulations are not appropriate for application to terminal services because they establish the service cost-in the first regulation-and the service fare-in the second regulationas attributes, even though terminals do not charge a service cost or fare (See Table 2).

Table 2. Terminal attributes and standards

\begin{tabular}{|l|l|l|l|}
\hline Sources & $\begin{array}{l}\text { Minister of } \\
\text { Administrative and } \\
\text { Bureaucratic Reform } \\
\text { Regulation of 25/2004 } \\
\text { as analyzed by } \\
\text { Mulyanto (2007) }\end{array}$ & $\begin{array}{l}\text { Minister of } \\
\text { Administrative and } \\
\text { Bureaucratic Reform } \\
\text { Regulation of 16/2014 } \\
\text { as analyzed by Sukesi } \\
\text { \& Muliasari (2018) }\end{array}$ & $\begin{array}{l}\text { Minister of } \\
\text { Transportation } \\
\text { Regulation of } \\
\text { by Angestiwi (2018) }\end{array}$ \\
\hline $\begin{array}{l}\text { Attributes } \\
\text { and }\end{array}$ & $\begin{array}{l}\text { Clarity of service and } \\
\text { information }\end{array}$ & $\begin{array}{l}\text { Specification of service } \\
\text { products }\end{array}$ & Security, Reliability, \\
\cline { 2 - 4 }
\end{tabular}




\begin{tabular}{|c|c|c|c|}
\hline \multirow[t]{16}{*}{ Standards } & & Service requirements & \multirow{14}{*}{$\begin{array}{l}\text { Convenience, and } \\
\text { Affordability }\end{array}$} \\
\hline & Service procedure & \multirow[t]{2}{*}{ Service procedures } & \\
\hline & Queue discipline & & \\
\hline & Service duration & \multirow[t]{2}{*}{ Service time } & \\
\hline & Service punctuality & & \\
\hline & $\begin{array}{l}\text { Certainty of service } \\
\text { cost }\end{array}$ & \multirow[t]{2}{*}{ Service fare } & \\
\hline & Reasonable cost & & \\
\hline & $\begin{array}{l}\text { Competence of service } \\
\text { personnel }\end{array}$ & \multirow[t]{3}{*}{ Staff competencies } & \\
\hline & Office security & & \\
\hline & Environmental comfort & & \\
\hline & $\begin{array}{l}\text { Courtesy and } \\
\text { hospitality of service } \\
\text { personnel }\end{array}$ & \multirow[t]{2}{*}{$\begin{array}{l}\text { Bus terminal staff } \\
\text { behavior }\end{array}$} & \\
\hline & $\begin{array}{l}\text { Discipline of service } \\
\text { personnel }\end{array}$ & & \\
\hline & $\begin{array}{l}\text { Completeness of } \\
\text { information }\end{array}$ & Service standard & \\
\hline & $\begin{array}{l}\text { Responsibilities of } \\
\text { service personnel }\end{array}$ & $\begin{array}{l}\text { Complaint suggestion, } \\
\text { feedback and response } \\
\text { mechanisms }\end{array}$ & \\
\hline & & & Safety \\
\hline & & & Equity \\
\hline
\end{tabular}

Source: Mulyanto (2007), Sukesi and Muliasari (2018) and Angestiwi (2018)

Moreover, the third regulation is the most complete regulation. Its completeness is evidenced by its wide range of standards. The standards of security, reliability, convenience and affordability cover all attributes described in the other regulations, while the safety and equity standards are not covered by other regulations. In addition, in the third regulation, there are 41 subattributes, while the second regulation has 29 sub-attributes, and the third regulation does not have subattributes (see Table 2).

The third regulation should be improved to be a user satisfaction assessment regulation. The regulation should not only establish terminal service standards but also require the assessment of user satisfaction with terminal services. In addition, based on the assumption of the importance of the service quality concept, an improvement of the regulation could provide an opportunity to adjust the service standards according to the service quality concept, i.e., from the attributes of security, safety, reliability, convenience, affordability and equity to the attributes of tangibility, reliability, responsiveness, assurance and empathy. Such improvements would result in future studies based on the regulation to be reputable studies of terminal user satisfaction assessment. 


\subsection{User Satisfaction with Terminals}

The assessment of user satisfaction with terminal service attributes based on the Minister of Transportation Regulation of 40/2015 revealed users' level of satisfaction. People do not feel very satisfied with terminal services. People are satisfied with the reliability, convenience, affordability and equity of terminal services. However, people are unsatisfied with the safety and security of terminal services. (See Figure 2).

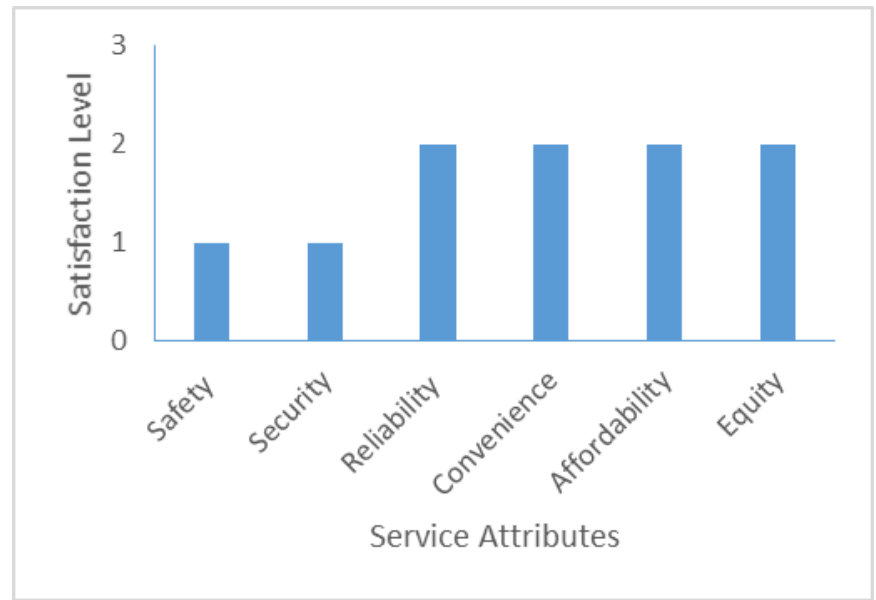

Figure 2. Level of User Satisfaction with Terminals

Note: 1: Unsatisfied, 2: Satisfied and 3: Very Satisfied

Terminals cannot provide perfect services. Perfect reliability is impeded by informal ticketing; perfect convenience is undermined by unclean toilets; perfect affordability is prevented by the unavailability of lockers, unavailability of battery charging facilities and limited parking areas; and perfect equity is impeded by the unavailability of a connecting facility from the terminal to the bus for disabled people. All of these factors cause users to be less than very satisfied with terminal services.

This finding is supported by the studies of the first and second regulations. They reported B-level or good grades for users' satisfaction with attributes similar to the reliability, convenience, affordability and equity attributes. No attributes were assessed as A-level or very good grades. Other studies have also reported similar findings. Mokhlis (2007) examined the relationship between terminal facilities, satisfaction and loyalty. Better terminal facilities resulted in higher satisfaction and loyalty. Lushakuzi and Daudi (2014) carried out a user satisfaction survey on ticketing, waiting room and canteen terminal facilities and services. Ishak \& Madsah (2016) studied integrated terminals and proposed standardized terminal attributes. Ikhlaq, et al. (2017) differentiated services provided by private versus state terminals. The private terminal provided better service than the state terminal. Lois et al. (2016) and Cheng et al. (2018) reported user perceptions of and satisfaction with services delivered in large and integrated terminals.

The findings do not indicate the importance of renovating and building new large terminals or privatizing state-owned terminals. However, they do indicate the importance of the generalization of terminal attributes through attribute standardization. Generalization and standardization should lead to the development of the same attributes for small terminals and 
state-owned terminals as those for private, large and integrated terminals. The generalization and standardization of terminal attributes should increase user satisfaction feeling.

Users have a low level of user satisfaction with safety and security terminal service attributes, even though safety and security officers, facilities and information are provided. Other studies have confirmed the low level of satisfaction with safety and security services in terminals. The study of the second regulation study reported low satisfaction with safety and security at Larangan Terminal. In addition, the study showed low satisfaction with safety conditions but satisfaction with the security conditions and safety and security attributes at Bunder Terminal. In the study of the first regulation, the grades for terminal security were $\mathrm{B} /$ good. In addition, the study did not report the security attribute to be a priority problem. However, among the highly ranked attributes with scores of 0.203 to 0.208 , the score for the security attribute was the lowest at 0.203 , which means that is score was near a $\mathrm{C}$ and dissatisfaction could occur.

Some studies based on accurate attributes have also confirmed users' dissatisfaction with security and safety. Mokhlis (2007) and Handriyati, Sunaryo, and Helia (2015) reported dissatisfaction with security and safety services in small terminals. In contrast, Lois, Monzón, and Hernández (2016); Ishak \& Madsah (2016); Ikhlaq, et al. (2017); and Cheng, Cao, Huang, and Wang (2018) observed user satisfaction with safety and security in large terminals. This difference indicates that the smaller the terminal is, the lower users' satisfaction with safety and security. This finding implies the importance of terminal safety and security attributes, as emphasized by Ikhlaq, et al. (2017).

The standardization of safety and security attributes is very important. However, terminal security should be standardized as well. Terminals with low levels of securityusually small and stated-owned terminals - allow all people to enter to the terminal, even those who do not have any specific reason to enter to the terminal. Even those with criminal intentions can easily enter the terminal. In addition, terminals with low security allow vehicles to enter the terminal. All of these factors decrease user satisfaction with safety and security. If the security and safety attributes of terminals are standardized and terminal secureness is improved, then users will feel greater satisfaction with those attributes.

\section{Conclusion}

The Minister of Transportation Regulation of 40/2015 establishes standards for terminal services. Terminals should fulfill these safety, security, reliability, convenience, affordability and equity standards. All of these standards should be established in order to provide services to terminal users.

The regulation is also used as a method to assess user terminal satisfaction. The regulation competes with the Minister of Administrative and Bureaucratic Reform Regulations of 16/2014 and 25/2004. Based on its recent date of issue, accuracy and completeness, this regulation is the best regulation. The standards also serve as appropriate attributes. However, the regulation regulates terminal service standards but does not regulate user satisfaction assessment surveys or require such assessments. Regulation improvement should be carried about by integrating requirements for satisfaction assessments and descriptions of methods. In addition, such improvement would involve developing accurate attributes based on the service quality concept. 
The third regulation has been implemented in terminals based on the attributes of safety, security, reliability, convenience, affordability and equity for terminal services users. However, users do not feel very satisfied with the terminal attributes. They feel satisfied with the reliability, convenience, affordability and equity, but they feel unsatisfied with the security and safety. To maximize user satisfaction, it is important to implement terminal standards as much as possible and to increase terminal security.

\section{References}

Abramović, B. (2017). Passenger's Satisfaction on Long Distance Terminals: Case Study City of Zagreb. Periodica Polytechnica Transportation Engineering, 45(1), 42-47. doi:10.3311/PPtr.9197

Angestiwi, T. (2018). Kajian Kondisi Fisik Terminal Leuwipanjang Berdasarkan Persepsi Penumpang. Jurnal Planologi, 15(1), 49-65. Retrieved from http://jurnal.unissula.ac.id/index.php/psa

Athiyah, U. H. (2018). Survei Kepuasan Masyarakat Di Balai Kesehatan Ibu Dan Anak Puskesmas Simolawang Kota Surabaya. Jurnal Penelitian Kesehatan Suara Forikes, 9 (1), 30-35.

Cheng, X., Cao, Y., Huang, K., \& Wang, Y. (2018). Modeling the Satisfaction of Bus Traffic Transfer Service Quality at a High-Speed Railway Station. Hindawi Journal of Advanced Transportation, 1-12. doi:10.1155/2018/7051789

Dana, D., Nane, M., Belete, M., Ergado, T., \& Labiso, T. (2016). A Survey of Passengers Satisfaction on Service Quality of Public Tranportation Sector: The Case of SNNPR, Ethiopia. International Journal of Multidisciplinary Academic Research, 4(5), 15-26.

de Oña, J., \& de Oña, R. (2014). Quality of Service in the public Transport based on Costumer Satisfaction Surveys: A review and Assesment of methodollogical approach. Transport Science, 49(3), 605-622. doi:10.1287/trsc.2014.0544

Dirlanudin, Sjafari, A., Nafisah, A. A., Hakim, A. L., \& Ade, H. (2014). Survey Indeks Kepuasan Masyarakat Kabupaten Pandeglang Tahun 2014. Jurnal Ilmiah Niagara, $\operatorname{VII}(2), 1-54$.

Gromure, V. (2007). New Perspectives of Coach Terminal as Important Element of Transport Infrastructure. Transport and Telecommunication, 8(2), 47-59.

Handriyati, A. A., Sunaryo, \& Helia, V. N. (2015). Analisis Kualitas Pelayanan Publik terhadap Kepuasan Konsumen dengan Menggunakan Metode Servperf-IPA-CSI. Teknoin, 21(4), 158-190.

Hermawan, W., Budiman, D., \& Hutagaol, P. (2016). Analisis Kepuasan Masyarakat Terhadap Kualitas Pelayanan Dalam Pendaftaran Tanah Pertama Kali Pada Kantor Pertanahan Kabupaten Bogor. Jurnal Ilmu Keluarga dan Konsumen, 9(1), 65-75.

Ikhlaq, S., Javid, M. A., \& Qayyum, T. I. (2017). Evaluation of User's Perceptions Regarding Performance Indicator of Intercity Bus Terminals in Lahore, Pakistan. Transport Problems, 12(2), 124-136. doi:10.208/tp.2017.12.2.12

Ishak, M. S., \& Madsah, N. (2016). The Building Suitability and an Existing Facility on Bus Station in Northern Malaysia. Modern Management Sciency and Engineering, 4(2), 112-118. Retrieved from www.scholink.org/ojs/index.php/mmse 
Liando, D. M. (2012). Implementasi Kebijakan Pembentukan Daerah Otonomi Baru dan Dampaknya bagi Kualitas Pelayanan Publik. JKAP (Jurnal Kebijakan dan Administrasi Publik), 16(2), 47-62.

Lois, D., Monzón, A., \& Hernández, S. (2016). Analysis of satisfaction factors at urban transport interchanges: Measuring travelers' attitudes to information, security and waiting. CIT2016 - XII Congreso de Ingeniería del Transporte València. València: Universitat Politècnica de València. doi:10.4995/CIT2016.2016.4207

Lukito, I. (2016). Implementasi Kebijakan Survei Kepuasan Masyarakat Pada Unit Penyelenggara Layanan Publik Kementerian Hukum Dan HAM. Jurnal Ilmiah Kebijakan Hukum, 10(3), 243-256.

Lushakuzi, S., \& Daudi, D. (2014). An analysis of user satisfaction on transit stop and station services on the Dar es Salaam-Arusha National Highway Road, Tanzania. Urban Transport, XX, 569-580. doi:10.2495/UT140471

Mokhlis, S. (2007). Passenger Satisfaction and Loyalty: A case of Inter-City Coach Travel in Malaysia. Benefit, 11(2). doi:10.23917/benefit.v11i2.1273

Mulyanto. (2007). Analisis Indeks Kepuasan Masyarakat pada UPTD Terminal Tirtonadi DLLAJ Kota Surakarta. Jurnal Ekonomi dan Kewirausahaan, 7(2), 137-149.

Normajatun, \& Herman, M. (2017). Indeks Kepuasan Masyarakat Terhadap Pelayanan Publik Pada Dinas Kependudukan Dan Pencatatan Sipil Kota Banjarmasin. As Siyasah, 2(1), 1-6.

Olivková, I. (2015). Model for Measuring Passenger Satisfaction and Assessing Mass Transit Quality. Journal of Public Transportation, 18(3), 52-70.

Pramusinto, A. (2007). Inovasi-inovasi pelayanan publik untuk pengembangan ekonomi lokal: Pengalaman beberapa daerah [Innovations of public service for developing local economy: Experience from some regions]. JKAP (Jurnal Kebijakan Dan Administrasi Publik),, 10(1), 1-18.

Qudsi Auliya, P. (2016). Pengaruh Tingkat Kualitas Pelayanan Terhadap Tingkat Kepuasan Pelanggan Listrik Pintar Prabayar Di Pt. Pln (Persero) Area Pelayanan Surabaya. Kebijakan dan Manajemen Publik, 4(1), 1-10.

Rizq, S., Djamaludin, M. D., \& Nurhadryani, Y. (2018). Analysis Of Service Quality Satisfaction Of E-Ktp Service At Public Administration And Civil Registration Office Of Bogor District. Journal of Consumer Sciences, 03(02), 55-65.

Santoso, P. S., Rosidah, H., \& Prasetyo, A. F. (2017). Indeks Kepuasan Masyarakat Pelayanan Perpustakaan Umum Kota Magelang. Jurnal Mahasiswa Administrasi Negara, 1(1), 11-20.

Sedayu, A. (2014). Service Improvement Target Of Purwoasri Terminal Kediri Using Ipa Method And Qfd. Eco Rekayasa, 10(1), 7-16.

Sukesi, \& Muliasari, R. S. (2018). Service Quality of Public Terminal Users in UPT-LLAJ East Java. Advances in Social Science, Education and Humanities Research, 186, 228-231.

Sukesi, \& Yunus, E. (2018). Service Quality in Public Transport Services of the Provicial Intercity Transportation (AKDP) in East Java Indonesia. Budapest International Research and Critics Institute-Journal (BIRCI-Journal), I(4), 161-109. doi:10.33258/birci.v1i4.105.g155

Sumino, \& Sutrischastini, A. (2017). Kepuasan Masyarakat Terhadap Pelayanan Polisi Sektor Bawang Kabupaten Banjarnegara. Jurnal Riset Manajemen, 4(2), 126 - 142. 
Witjaksono, A., Suyatno, \& Soeparno. (2018). Analysis of Bus Station Services with Importance-Performance Analysis: Empirical Results of Gerbangkertosusila Region. IOP Conf. Series: Materials Science and Engineering 288 ( (pp. 1-5). IOP Publishing.

Yuan, Y., Yang, M., Wu, J., Rasouli, S., \& Lei, D. (2019). Assesing bus transit service from the perspective of elderly passengers in Harbin, China. International Journal of Sustainable Transportation, 12(10), 761-776. doi:10.1080/15568318.2018.1512691

Yudiatmaja, E. W., Alfiandri, \& Hidayat, R. (2017). Far from Fire: The service delivery quality gap plaguing Indonesian Ports . JKAP (Jurnal Kebijakan dan Administrasi Publik) , 21(1), 31-42. 